\title{
Spatial genetic structure in Pinus cembroides Zucc. at population and landscape levels in central and northern Mexico
}

Luis C García-Zubia ${ }^{1}$, Javier Hernández-Velasco ${ }^{1}$, José C Hernández-Díaz ${ }^{1}$, Sergio L Simental-Rodríguez ${ }^{1}$, Carlos A López-Sánchez ${ }^{2}$, Zulema Quiñones-Pérez ${ }^{3}$, Artemio Carrillo-Parra ${ }^{1}{ }^{1}$, Christian Wehenkel ${ }^{\text {Corresp. } 1}$

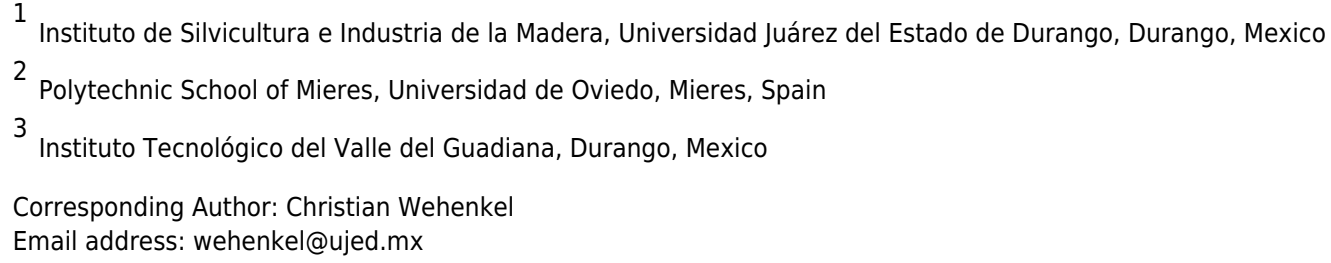

Background Spatial genetic structure (SGS) analysis is a powerful approach to quantifying gene flow between trees, thus clarifying the functional connectivity of trees at population and landscape scales. The findings of SGS analysis may be useful for conservation and management of natural populations and plantations. Pinus cembroides is a widely distributed tree species, covering an area of about 2.5 million hectares in Mexico. The aim of this study was to examine five natural seed stands of $P$. cembroides in the Sierra Madre Occidental to determine the SGS at population (within the seed stand) and landscape (among seed stands) levels in order to establish guidelines for the conservation and management of the species. We hypothesized that $P$. cembroides, in which the seeds are dispersed by birds and mammals, creates weaker SGS than species with winddispersed seeds. Methods DNA fingerprinting was performed using the amplified fragment length polymorphism (AFLP) technique. In order to estimate the SGS at population and landscape levels, we measured the geographical (spatial) distance as the Euclidean distance. We also estimated the genetic distances between individuals using the pairwise kinship coefficient. Results The results showed non-significant autocorrelation in four out of five seed stands studied (i.e. a mainly random distribution in the space of the genetic variants of $P$. cembroides at population level). Discussion SGS was detected at the landscape scale, supporting the theory of isolation by distance as a consequence of restricted pollen and seed dispersal. However, the SGS may also have been generated by our sampling strategy. We recommended establishing a close network of seed stands of $P$. cembroides to prevent greater loss of local genetic variants and alteration of SGS. We recommend seed stands of $P$. cembroides of a minimum width of $225 \mathrm{~m}$. 
1 Spatial genetic structure in Pinus cembroides Zucc. at

2 population and landscape levels in central and

3 northern Mexico

4

5

6

7

8

\section{Luis Cesar García-Zubia ${ }^{1}$, Javier Hernández-Velasco ${ }^{1}$, José Ciro Hernández-Díaz ${ }^{1}$, Sergio} Leonel Simental-Rodríguez ${ }^{1}$, Carlos Antonio López-Sánchez ${ }^{2}$, Carmen Zulema Quiñones-Pérez ${ }^{3}$, Artemio Carrillo-Parra ${ }^{1}$, Christian Wehenkel ${ }^{*}$

${ }^{1}$ Instituto de Silvicultura e Industria de la Madera, Universidad Juárez del Estado de Durango, Durango, México.

${ }^{2}$ Polytechnic School of Mieres, Universidad de Oviedo, Mieres, Spain

${ }^{3}$ Instituto Tecnológico del Valle del Guadiana, Durango, México.

*Corresponding Author: Christian Wehenkel

Boulevard Guadiana 501, Ciudad Universitaria, C.P. 34120 Durango, México

Email address: wehenkel@ujed.mx

\section{Abstract}

\section{Background}

Spatial genetic structure (SGS) analysis is a powerful approach to quantifying gene flow between trees, thus clarifying the functional connectivity of trees at population and landscape scales. The findings of SGS analysis may be useful for conservation and management of natural populations and plantations. Pinus cembroides is a widely distributed tree species, covering an area of about 2.5 million hectares in Mexico. The aim of this study was to examine five natural seed stands of P. cembroides in the Sierra Madre Occidental to determine the SGS at population (within the seed stand) and landscape (among seed stands) levels in order to establish guidelines for the conservation and management of the species. We hypothesized that $P$. cembroides, in which the seeds are dispersed by birds and mammals, creates weaker SGS than species with wind-dispersed seeds.

\section{Methods}

DNA fingerprinting was performed using the amplified fragment length polymorphism (AFLP) technique. In order to estimate the SGS at population and landscape levels, we measured the geographical (spatial) distance as the Euclidean distance. We also estimated the genetic distances between individuals using the pairwise kinship coefficient.

\section{Results}

The results showed non-significant autocorrelation in four out of five seed stands studied (i.e. a mainly random distribution in the space of the genetic variants of $P$. cembroides at population level). 


\section{Discussion}

41 SGS was detected at the landscape scale, supporting the theory of isolation by distance as a

42 consequence of restricted pollen and seed dispersal. However, the SGS may also have been

43 generated by our sampling strategy. We recommended establishing a close network of seed

44 stands of $P$. cembroides to prevent greater loss of local genetic variants and alteration of SGS.

45 We recommend seed stands of $P$. cembroides of a minimum width of $225 \mathrm{~m}$.

46

47 48

\section{Introduction}

50 Gene flow mediated by exchange of pollen and seed within and among tree populations is 51

Keywords: gene flow, seed stands, Sierra Madre Occidental, isolation by distance necessary to maintain the long-term viability of forest species. Gene flow can stabilize local genetic variation and spread potentially adaptive genes (Van Dyck \& Baguette, 2005). However, spatially limited gene flow can generate spatial genetic structure (SGS), i.e. the non-random geographical distribution of genetic variation caused by isolation by distance gene dispersal (Wright, 1938). Tree species with wind-dispersed seeds and that occur at low densities tend to generate stronger SGS in their seedlings than species with animal-dispersed seeds or that occur at high densities (Hamrick, Murawski \& Nason, 1993). Moreover, limited seed dispersal that leads to neighbors being closely related also impacts demographic and reproductive processes (Hamrick, Murawski \& Nason, 1993).

SGS analysis is a powerful approach to quantifying gene flow between trees (Segelbacher et al., 2010), thus clarifying the functional connectivity of trees at population and landscape scale (Van Dyck \& Baguette, 2005). SGS can also be affected by mating systems, historical events and ecological and other evolutionary forces (such as selection and genetic drift), and it is therefore a crucial aspect of plant evolutionary processes and population dynamics (Epperson, 2003; Rousset, 2004; Vekemans \& Hardy, 2004). The findings of SGS analysis may be useful for conservation and management of natural populations and plantations (McCue, Buckler \& Holtsford, 1996).

The pattern of SGS revealed by autocorrelation analysis is greatly affected by the distance class width, sampling intensity and the total area sampled (Epperson \& Li, 1996; Peakall, Ruibal \& Lindenmayer, 2003; Double et al., 2005). Strong autocorrelation may occur when the spatial scale of sampling is smaller than the scale of the SGS (Cavers et al., 2005). In order to reduce bias due to the distribution, sampling along a fine mesh of transects in multiple dimensions and stratified sampling is recommended, thus combining high-density local sampling with a broader sampling coverage (Vekemans \& Hardy, 2004). Overall, the line-transect scheme seems to perform slightly better than the simple-random scheme in parameter estimation and to be more efficient for encompassing broad spatial scales (Zeng et al., 2010).

SGS is also often associated with substantial stochastic variation due to genetic drift and a limited number of polymorphic genetic markers. Thus, gene markers such as allozymes, which provide few loci, are not adequate (Slatkin \& Arter, 1991). Highly polymorphic markers (e.g. 
80 microsatellites) or markers facilitating many loci (e.g. amplified fragment length polymorphism

81 [AFLP] markers) are therefore preferred in SGS analysis (Vekemans \& Hardy, 2004). The

82 advantage of using AFLP markers is that they are produced randomly throughout the whole

83 genome and are highly reproducible and more sensitive than other markers for characterizing

84 SGS (e.g. Leinemann et al., 2013, 2014). Moreover, AFLP markers are more precise (lower

85 standard deviation) when the inbreeding coefficient is estimated independently (Mueller \&

86 Wolfenbarger, 1999; Hardy, 2003).

87 Pinus cembroides Zucc. (1832) is one of eleven to fourteen taxa known as pinyon pines and

88 belonging to the subsection Cembroides, section Parrya, subgenus Ducampopinus (Gernandt,

89 Liston \& Piñero, 2003). The monoecious $P$. cembroides is widely distributed, covering an area of

902.5 million hectares in Mexico (CONAFOR, 2009). The largest populations are found in the

91 states of Chihuahua, Coahuila, Durango, Nuevo León, Hidalgo and Zacatecas. Individual

92 specimens of $P$. cembroides often grow in mildly acidic soils (mean $\mathrm{pH} 5.3$, with $\mathrm{H}+$

93 representing on average $25 \%$ of the total exchangeable cations), under a warm xerophytic

94 temperate climate (Wehenkel et al., 2015), almost always occupying transition zones between

95 desert vegetation in arid climates and the more humid mountain forests (Rzedowski, 1978). The

96 International Union for Conservation of Nature (IUCN) Red List guidelines indicate "minor

97 concern" regarding the status of P. cembroides (IUCN, 2015). Pinus cembroides, which is also

98 well-known for producing nutritious, cholesterol-free nuts (López-Mata, 2001; Luna-Cavazos,

99 Romero-Manzanares \& García-Moya, 2008; Amr \& Abeer, 2011), is suitable for reforesting arid,

100 semi-arid and eroded areas.

101 Although phylogenetic analysis has been conducted (e.g. Flores-Rentería et al., 2013), to the best

102 of our knowledge, only one study has investigated the SGS within and among $P$. cembroides

103 stands (three) in the state of Durango, Mexico (Hernández-Velasco et al., 2016). These authors

104 did not find any evidence of significant SGS at the local scale, suggesting that the genetic

105 variants of these species are almost always randomly distributed in space, probably due to high

106 wind pollination and seed dispersal by animals (Vekemans \& Hardy, 2004). The significant level

107 of SGS observed at a larger scale, however, may be the result of isolation by distance gene

108 dispersal between populations.

109 The aim of this study was to examine five $P$. cembroides seed stands in the Sierra Madre

110 Occidental, to determine the SGS at population (within each seed stand) and landscape (among

111 seed stands) levels (Table 1) in order to establish guidelines for the conservation and

112 management of this species. We hypothesized that $P$. cembroides, in which the seeds are usually

113 dispersed by birds and mammals (Hubbard \& McPherson, 1997; Richardson, 2000), creates

114 weaker SGS than pine species with wind-dispersed seeds (Hamrick, Murawski \& Nason, 1993).

115

116 Materials \& Methods

117

118

Study area 
119 The following five P. cembroides seed stands were sampled: Mesa Azul (PC-MA) and 120 Baquiriachi (PC-BQ) in the state of Chihuahua, and Mesa de la Majada (PC-MM), Los Adobe 121 (PC-AD) and Cordón del Toro (PC-CT) in the state of Durango (Table 1; Fig. 1). The seed 122 stands were established according to the current Mexican norm for forest germplasm (NMX-AA123 SC-169-2016; Hernández-Velasco et al., 2016). The five seed stands were growing on slightly 124 acidic soil. The elevation ranges between 2,218 and 2,631 $\mathrm{m}$ above sea level in the study area, 125 with annual rainfall between 498 and $514 \mathrm{~mm}$. The mean temperature varies between about 11.0 126 and $13.1^{\circ} \mathrm{C}$ (Table 2). The size of the seed stands ranged from 4.2 to 13.8 hectares. The mean 127 distance to the next sampled tree varies from 54 to $81 \mathrm{~m}$, depending on the stand considered 128 (Table 1). Needles were collected from 34-35 randomly chosen trees in each stand. These sample trees, which were adult, dominant and occurred in the older age group, were a part of 130

131

132

133

134

135

136

137

138

139

140

141

142

143

144

145

146

147

148

149

150

151

152

153

154

155

156

157

158 previously selected adult phenotypes (trees) in each stand and were superior in terms of dimension, and pest-resistance, relative to the average tree in the same seed stands (for information about selection criteria of plus trees, see NMX-AA-SC-169-2016 and HernándezVelasco et al., 2016).

\section{Extraction of DNA and genetic markers}

DNA fingerprinting was performed using the amplified fragment length polymorphism (AFLP) technique, according to the protocol described by Vos et al. (1995) and modified by Ávila-Flores et al. (2016). The DNA was extracted from the needles using the commercial DNeasy 96 plant kit (QIAGEN) and digested simultaneously with the restriction enzymes EcoRI and MseI. The primer combination E01/M03 (EcoRI-A/MseI-G) was used in the pre-AFLP amplification and the primer pair E35 (fluorescently-labelled with FAM) and M63+C (MseI-GAAC) in the selective amplification step.

All PCR reactions were conducted in a Peltier thermocycler (PTC-200 Version 4.0, MJ Research). The amplified restriction products were electrophoretically resolved in a genetic analyzer (ABI 3100) together with the GeneScan500 ROX (fluorescent dye ROX), and the size of the AFLP fragments was determined with GeneScan 3.7.1 and Genotyper 3.7. (Applied Biosystems). The AFLP bands were classified as present (1) or absent (0) in each individual, which was thus considered dominant or recessive (Simpson, 1997), i.e. detection of a band indicated the dominant genetic variant (the "plus phenotype") (Krauss, 2000; Bonin et al., 2004).

\section{Analysis of the spatial structure of AFLP data}

In order to estimate the SGS at population and landscape levels, the geographical (spatial) distance was measured as the Euclidean distance and the genetic distance was estimated from the pairwise kinship coefficient $\left(F_{i j}\right)$ (Hardy, 2003). $F_{i j}$ was measured using SPAGeDi v1.4 (Vekemans \& Hardy, 2004).

For statistical reasons, we defined the width of spatial distance classes as including a minimum of 30 pairwise comparisons per distance class (Doligez \& Joly, 1997). Thus, the smallest distance class width should not be less than $125 \mathrm{~m}$ at the local scale (i.e. within each of the five 
159

160

161

162

163

164

165

166

167

168

169

170

171

172

173

174

175

176

177

178

179

180

181

182

183

184

185

186

187

188

189

190

191

192

193

194

195

196

197

198

seed stands). The SGS statistics were therefore calculated for $125 \mathrm{~m}$ distance-class structures. However, as this autocorrelation technique are not capable of forecasting an appropriate analytical scale (Peakall, Ruibal \& Lindenmayer, 2003; Double et al., 2005), we also calculated the SGS for distance class widths between 25 and $700 \mathrm{~m}$ (in $25 \mathrm{~m}$ steps from 25 to $300 \mathrm{~m}$, in 50 $\mathrm{m}$ steps from 300 to $700 \mathrm{~m}$ ), although the data did not comply with the condition of a minimum of 30 pairwise comparisons for the 25, 50, 75 and $100 \mathrm{~m}$ distance class widths.

At the large or landscape scale (among stands), the SGS was computed for distance class widths of six, seven, eight, $86 \mathrm{~km}$ and $168 \mathrm{~km}$ for a minimum of 2,900 tree pairs per distance class. For each spatial distance class, the $99 \%$ confidence interval (CI) was computed using 999 permutations (with SPAGeDi) (Manly, 1997). The probability value $(P)$ was then computed for each spatial distance class and coefficient. After Bonferroni correction (Hochberg, 1988), the corrected critical $p$ value (significance level $\alpha^{*}=0.0005$ ) was calculated by dividing the original critical $p$ value ( 0.05$)$ by the number of comparisons or hypotheses $(m=100)$. Thus, the Bonferroni critical value of $P$ was $1-\alpha^{*}=0.9995$ in this study (Hernández-Velasco et al., 2016).

The pairwise kinship coefficient $\left(F_{i j}\right)$ for dominant markers in diploids was computed and averaged over a set of distance classes to detect the SGS. The $F_{i j}$ coefficient, computed using SPAGeDi ver. 1.4, measures the occurrence of identical alleles at a given locus in a pair of individuals (Hardy, 2003), i.e. it estimates the ratio of differences of probabilities of identity (Rousset, 2002). If individuals are more closely related than individuals randomly chosen from the "reference" population, the relative kinship coefficients will have positive values.

Consequently, negative values of the $F_{i j}$ indicate that $i$ and $j$ are less closely related on average than random individuals (Hardy, 2003).

\section{PCoA analysis}

The binary AFLP data matrix was also analyzed by Principal Coordinate Analysis (PCoA), and Nei's Genetic Distance (Nei, 1972, 1978), which was determined using GenAlEx v6, to compute the genetic separation between the seed stands and trees. The first two coordinates were used to graphically display genetic differentiation of populations and individuals.

\section{Detecting AFLP loci under natural selection (outlier AFLP loci)}

In the present study, the SGS of AFLP markers under natural selection may be an indicator of environmentally adapted provenances (Epperson, 1992; Stingemore \& Krauss, 2013). Candidate AFLP loci under natural selection were determined using differences in allele frequencies between populations, and the multinomial Dirichlet model and the Reversible Jump Markov Chain Monte Carlo algorithm were implemented in BayeScan v2.1 (Foll \& Gaggiotti, 2008). AFLP markers were used as purely dominant binary data, but the inbreeding coefficients $\left(F_{I S}\right)$, used to estimate allele frequencies, were not able to be estimated from binary data. Therefore, BayeScan allowed $F_{I S}$ to move freely within its prior range in order to still incorporate the uncertainty associated with this parameter. 
199

200

201

202

203

204

205

206

207

208

209

210

211

212

213

214

215

216

217

218

219

220

221

222

223

224

225

226

227

228

229

230

231

232

233

234

235

236

237

238

A negative locus-specific component $(A)$ value with posterior probability $>0.99$ indicates possible balancing or purifying selection, and positive values of the $A$ and posterior probability $>$ 0.99 indicate diversifying selection (false discovery rates $<0.01$ ) (Foll \& Gaggiotti, 2008; Foll et al., 2010). We used the parameter values of the chain and the model reported by Friedrich et al. (2018): output number of iterations (5,000), thinning interval size (10), pilot runs (20), length of pilot runs $(5,000)$, additional burn in $(50,000)$, prior odds for the neutral model $(10)$, a lower boundary for uniform prior in the inbreeding coefficient $F_{I S}(0)$ and a higher boundary for uniform prior in $F_{I S}(1)$.

\section{Clark and Evans aggregation index}

The aggregation index ( $C E$ ) proposed by Clark \& Evans (1954) was calculated using Spatial Genetic Software v1.0. The values obtained indicate the spatial structure, where $C E<1$ represents an aggregated distribution, $C E=1$ indicates a random structure and $C E>1$ indicates a regular distribution. The statistical significance of $C E$ was calculated using permutation tests (Degen, 2000).

\section{Results}

The combination of the AFLP primers resulted in 281 polymorphic bands of $75-450$ bp across the 173 individual Pinus cembroides trees analyzed. No candidate AFLP loci under differential selection (putative adaptive AFLP) were detected (posterior probability $>0.99$ and false discovery rates $<0.01)$.

At the fine scale (within each of the five seed stands), significant autocorrelation $(P>0.9995$, after Bonferroni correction) was only observed in PC-MA. In particular, significant autocorrelation was only detected in the first five distance class widths (i.e. $0-100 \mathrm{~m}, 0-125 \mathrm{~m}$, $0-150 \mathrm{~m}, 0-175 \mathrm{~m}$ and $0-200 \mathrm{~m}$ of the class sizes 100,125, 150,175 and $200 \mathrm{~m}$ ) and the distance classes $50-75 \mathrm{~m}$ and $50-100 \mathrm{~m}$ (Table 3 ). $F_{i j}$ was weakly positive in the first distance class in five distance class widths $(0-75 \mathrm{~m}$ to $0-175 \mathrm{~m})$ in PC-MA and in a few other distance classes in PC-CT and PC-AD. However, this index became more and more negative in larger distance class widths ( $>0-125 \mathrm{~m}$ in PC-AD and $>0-200 \mathrm{~m}$ in PC-MA) (Tables 3 and 4). The values of the aggregation index of Clark and Evans (CE) indicated that the spatial distribution of the seed trees under study was only clumped in PC-MA and PC-AD (Tables 3 and 4). At the large scale (among seed stands), the individuals in the distance classes of $0-6 \mathrm{~km}, 0-7$ $\mathrm{km}, 0-8 \mathrm{~km}$ and $0-86 \mathrm{~km}$ were genetically more closely related than random individuals from the "reference group" calculated by Fij. On the other hand, the individuals in other distance classes ( 0 - $168 \mathrm{~km}, 86-172 \mathrm{~km}, 172-258 \mathrm{~km}$ and $258-344 \mathrm{~km})$ were found to be genetically significantly different, according to the Fij values (Table 5).

At the large or landscape level (among seed stands, 6 to $168 \mathrm{~km}$ distances), the Principal Coordinate Analysis (PCoA - Coord. 1 vs. 2) clearly separated the five stands into four clusters (Fig. 2): PC-CT along with PC-MM located in Durango, PC-MA (Chihuahua), PC-AD (Durango) and PC-BQ (Chihuahua). However, the PCoA with Coordinate 1 vs. 3 revealed only 
239 three groups, and the three seed stands from Durango were grouped together (Fig. 3). The first

240 two coordinates explained $69.7 \%$ of the variation in AFLP, and the first three coordinates

241 explained $93.4 \%$ of the corresponding variation.

242 In a PCoA at the individual level, the first two coordinates explained a much lower percentage of

243 the variation in AFLP (4.4 and 3.1\%). Together the first three coordinates explained 10.1\% of

244 the variation. By plotting the first two coordinates, the 173 individual $\mathrm{PC}$ trees were not

245 generally divided in separate groups. PC-MM had the largest mean TD, PC-BQ had the largest

246 mean GD and PC-MA had the smallest mean GD (Fig. 4).

247

248 Discussion

249 The results showed non-significant autocorrelation in $80 \%$ (four out of five) of the natural seed

250

251

252

253

254

255

256

257

258

259

260

261

262

263

264

265

266

267

268

269

270

271

272

273

274

275

276

277

278 stands studied (Tables 3 and 4), i.e. a mainly random distribution in the space of the genetic variants of the Pinus cembroides at the population level. The results thus did not confirm our hypothesis of weak SGS at the population level. Other studies of several Mexican pine species such as $P$. cembroides, $P$. discolor, $P$. durangensis, $P$. teocote (Hernández-Velasco et al., 2016), $P$. arizonica and $P$. cooperi (Friedrich et al., 2018) also detected no too weak SGS at the local scale. Especially for P. cembroides, Hernández-Velasco et al. (2016) found no SGS and smaller mean Tanimoto distances (mean 0.52$)$ in three small $(\leq 12.1$ ha), closely spaced $(\leq 10 \mathrm{~km})$ seed stands.

These results can be explained by the random patterns and large distances over which pollen and seeds are dispersed (Ennos, 1994), along with a breeding system with a low selfing rate, nonsignificant local genetic drift and selection, and low population density supporting larger gene dispersal distances (Vekemans \& Hardy, 2004). This particularly applies to P. cembroides, a species with wind-dispersed pollen, animal-dispersed seed and generally low population density (Little Jr, 1977; McCune, 1988; Tomback \& Linhart, 1990), all of which favour gene flow (Vekemans \& Hardy, 2004). This explanation is supported by the almost always negative pairwise kinship coefficients $\left(F_{i j}\right)$ (Tables 3 and 4 ) and greater genetic diversity than in other Mexican pine species (Wehenkel et al., 2015; Hernández-Velasco et al., 2016). Furthermore, the overlapping seed shadows and demographic mortality may also result in non-significant SGS (Hamrick, Murawski \& Nason, 1993; Epperson \& Alvarez-Buylla, 1997; Parker et al., 2001; Fuchs \& Hamrick, 2010). In our study, the trees sampled in each stand were heath, adult, dominant and occurred in the older age group; it is possible that SGS would have been revealed if other (younger) age classes had been sampled, as with Cecropia obtusifolia (Epperson \& Alvarez-Buylla, 1997). Moreover, the sampling strategy may also be a decisive factor (see below).

Significant spatial autocorrelation along with almost always positive $F_{i j}$ was only observed in the first distance classes in the $0-100$ to $0-200 \mathrm{~m}$ class widths. The autocorrelation was also almost significant (together with a positive $F_{i j}$ ) in the $0-75 \mathrm{~m}$ distance class, indicating family structure (in these distance classes). However, the first classes in the smallest widths tested (0-25 and $0-50 \mathrm{~m}$ ) showed no significant SGS along with the two most negative $F_{i j}$ in this study (Table 
279 3). However, the lack of significance may have been due to an insufficient number of tree pairs 280 (i.e. insufficient repetitions) in these small class sizes. We therefore assumed that there was no 281 significant family structure in smaller groups of adult, dominant and older $P$. cembroides in PC282 MA. However, in the first classes in larger distance class widths (i.e., $0-225$ to $0-700 \mathrm{~m}$ ) in 283 PC-MA, also with sufficient tree pairs for statistical analysis, this index became more and more

284

285

286

287

288

289

290

291

292

293

294

295

296

297

298

299

300

301

302

303

304

305

306

307

308

309

310

311

312

313

314

315

316

317

318 negative (Table 3 ). Thus, the $P$. cembroides tree pairs became more and more genetically different and larger from a distance of $200 \mathrm{~m}$, indicating weakened gene flow, probably caused by isolation by distance gene dispersal.

The significant SGS, detected only in PC-MA, may have been caused by the range of spatial scales and the sampling strategy in this stand. In contrast to the other four stands, PC-MA was linear and had the longest linear expansion $(2,300 \mathrm{~m}$ rather than $<1,300 \mathrm{~m})$ (Fig. 5), i.e. the range of spatial scale encompassed by the sample was the largest in this study. In addition, the larger the range, the better the regression performance in the SGS analysis (Heuertz et al., 2003; Vekemans \& Hardy, 2004). Moreover, the sampling strategy was similar to a line-transect scheme, which may perform slightly better than the simple-random scheme used in our study (Zeng et al., 2010). The significant pattern of SGS in PC-MA is equal to that observed in the vast majority of studies which have often detected SGS only at the smallest spatial scales studied. This finding has usually been interpreted as a consequence of an isolation-by-distance process with restricted seed dispersal within plant populations (e.g. Sokal \& Wartenberg, 1983; Streiff et al., 1998; Sork et al., 2002; Vekemans \& Hardy, 2004).

Significant SGS was observed (Table 5) at the landscape scale (among the five seed stands), supporting the theory of isolation by distance as a consequence of restricted pollen and seed dispersal (Wright, 1938). However, the lack of outlier AFLP loci indicated that local selection was not an important factor in relation to SGS in this study (Epperson, 1992).

The biological meaning of the spatial genetic patterns can easily be misinterpreted without highly variable markers, appropriate sampling or detailed ecological data such as the age, sex and social status of the individuals sampled (Double et al., 2005). We used i) stable markers, but with many loci (281 AFLP) (Vekemans \& Hardy, 2004; Cavers et al., 2005), ii) the social status (dominant trees), iii) sex (monoecious) and iv) proximate age (the higher age-group) of the individuals sampled. However, the sampling number and structure may represent two of the weakest points in this study. More than 35 samples per stand and a larger range of spatial scale are probably needed to detect weak SGS, which is expected in tree species with wind-dispersed pollen and animal-dispersed seed (Hamrick, Murawski \& Nason, 1993; Vekemans \& Hardy, 2004), such as the wingless seed of $P$. cembroides (Richardson, 2000). The line-transect scheme may also be the best sampling strategy (Zeng et al., 2010).

Although we detected SGS at landscape (among seed stands) level, our study is not strong enough in relation to coverage of the study site and intermediate distance intervals, as only five stands were studied. In addition, the range of spatial scales included in the sample was not maximized (Vekemans \& Hardy, 2004). Moreover, if genetic variation is arranged clinally, then sampling only at well-separated stands in this continuum may create an artificial set of "isolated

Peer) reviewing PDF | (2019:07:39338:1:1:NEW 19 Sep 2019) 
319 populations" that nevertheless are connected by the unsampled trees in between. Furthermore, if 320 the distance classes are set exactly to the distances that separate the sampling points, this effect

321 may be exaggerated.

322

323

\section{Conclusions}

324

325

On the basis of the SGS analysis at the local scale and also assuming that SGS was weak, we

326 concluded that seed stands of $P$. cembroides may represent small-scale units. However, a

327

328

329

330

331

332

333

334

335

336

337

338

339

340

341

342

343

344

345

346

347

348

349

350

351

352

353

354

355

356

357

358

minimum width of $225 \mathrm{~m}$ is required in these stands to produce seeds without significant loss of genetic variation, because all classes with distance class size $225 \mathrm{~m}$ or larger did not show significant SGS and $F_{i j}$ was negative. Indeed, the Mexican norm for forest germplasm (NMXAA-SC-169-2016) requires a minimum stand size of two hectares (e.g. 141 x $141 \mathrm{~m}$ ), which, however, may be too small.

On the basis of the SGS analysis, we conclude that establishment of a close network of PC seed stands separated by a maximum distance of $6 \mathrm{~km}$ can prevent greater loss of local genetic variants and alteration of SGS. However, we estimate that establishing such a high density of seed stands would not be economically feasible in forest management and conservation plans. In addition, all of the AFLP loci identified are probably neutral markers. They may consequently be more variable and more differentiated than adaptive markers, as a result of isolation and genetic drift (Petit et al., 2001; McKay \& Latta, 2002). Definition of seed collection zones by differences in genetic adaptation could therefore result in an overly dense network of seed stands.

\section{Acknowledgements}

We thank the Comisión Nacional Forestal (CONAFOR), Mexico for their helpful assistance and allocation of the data set.

\section{References}

Amr AR, Abeer EEK. 2011. Hypolipideimic and hypocholestermic effect of pine nuts in rats fed high fat, cholesterol-diet. World Appl. Sci. J. 15(12): 1667-1677.

Ávila-Flores IJ, Hernández-Díaz JC, González-Elizondo MS, Prieto-Ruíz JÁ, Wehenkel C. 2016. Degree of Hybridization in Seed Stands of Pinus engelmannii Carr. In the Sierra Madre Occidental, Durango, Mexico. PLOS ONE 11(4): e0152651. DOI: 10.1371/journal.pone.0152651.

Bonin A, Bellemain E, Bronken EP, Pompanon F, Brochmann C, Taberlet P. 2004. How to track and assess genotyping errors in population genetics studies. Molecular Ecology 13:32613273. DOI: 10.1111/j.1365-294X.2004.02346.x.

Cavers S, Degen B, Caron H, Lemes MR, Margis R, Salgueiro F, Lowe AJ. 2005. Optimal sampling strategy for estimation of spatial genetic structure in tree populations. Heredity 95:281-289. DOI: 10.1038/sj.hdy.6800709. 
359

360

361

362

363

364

365

366

367

368

369

370

371

372

373

374

375

376

377

378

379

380

381

382

383

384

385

386

387

388

389

390

391

392

393

394

395

396

397

398

Clark PJ, Evans FC. 1954. Distance to Nearest Neighbor as a Measure of Spatial Relationships in Populations. Ecology 35:445-453. DOI: 10.2307/1931034.

Comisión Nacional Forestal (CONAFOR). 2009. Inventario Nacional Forestal y de Suelos de México 2004-2009 - 1st ed. Comisión Nacional Forestal, Zapopan, Jalisco, México.

Degen B. 2000. SGS: Spatial Genetic Software. Computer program and user's manual. Available via http:/kourou. cirad. fr/genetique/software. html.

Deichsel G, Trampisch HJ. 1985. Clusteranalyse und Diskriminanzanalyse Gustav Fischer Verlag Stuttgart 1. New York 135.

Doligez A, Joly HI. 1997. Genetic diversity and spatial structure within a natural stand of a tropical forest tree species, Carapa procera (Meliaceae), in French Guiana. Heredity 79:7282. DOI: 10.1038/hdy.1997.124.

Double MC, Peakall R, Beck NR, Cockburn A. 2005. Dispersal, philopatry, and infidelity: dissecting local genetic swtructure in superb fairy-wrens (Malurs Cyaneus). Evolution 59(3):625-635. DOI:10.1111/j.0014-3820.2005.tb01021.x

Ennos RA. 1994. Estimating the relative rates of pollen and seed migration among plant populations. Heredity 72:250-259. DOI: 10.1038/hdy.1994.35.

Epperson BK, Alvarez-Buylla ER. 1997. Limited seed dispersal and genetic structure in life stages of Cecropia obtusifolia. Evolution 51:275-282. DOI:10.1111/j.1558-

5646.1997.tb02409.x

Epperson BK, Li T. 1996. Measurement of genetic structure within populations using Moran's spatial autocorrelation statistics. Proc. Natl. Acad. Sci. USA 93:10528-10532. DOI: 10.1073/pnas.93.19.10528.

Epperson BK. 1992. Spatial structure of genetic variation within populations of forest trees. New Forests 6: 257-278. DOI: 10.1007/BF00120648.

Epperson BK. 2003. Covariances among join-count spatial autocorrelation measures. Theor. Popul. Biol. 64:81-87. DOI: 10.1016/S0040-5809(03)00023-6.

Flores-Rentería L, Wegier A, Ortega Del Vecchyo D, Ortíz-Medrano A, Piñero D, Whipple A V., Molina-Freaner F, Domínguez CA. 2013. Genetic, morphological, geographical and ecological approaches reveal phylogenetic relationships in complex groups, an example of recently diverged pinyon pine species (Subsection Cembroides). Mol. Phylogenet. Evol. 69:940-949. DOI: 10.1016/j.ympev.2013.06.010.

Foll M, Fischer MC, Heckel G, Excoffier L. 2010. Estimating population structure from AFLP amplification intensity. Molecular Ecology 19:4638-4647. DOI: 10.1111/j.1365294X.2010.04820.x.

Foll M, Gaggiotti O. 2008. A Genome-Scan Method to Identify Selected Loci Appropriate for Both Dominant and Codominant Markers: A Bayesian Perspective. Genetics 180:977-993. DOI: 10.1534 /genetics.108.092221.

Friedrich SC, Hernández-Díaz JC, Leinemann L, Prieto-Ruíz JA, Wehenkel C. 2018. Spatial genetic structure in seed stands of Pinus arizonica Engelm. and Pinus cooperi Blanco in the state of Durango, Mexico. Forest Science 64(2): 191-202. DOI: 10.1093/forsci/fxx007. 
399

400

401

402

403

404

405

406

407

408

409

410

411

412

413

414

415

416

417

418

419

420

421

422

423

424

425

426

427

428

429

430

431

432

433

434

435

436

437

438

Fuchs EJ, Hamrick JL. 2010. Spatial genetic structure within size classes of the endangered tropical tree Guaiacum sanctum (Zygophyllaceae). Am. J. Bot. 97:1200-1207. DOI: 10.3732/ajb.0900377.

Gernandt D, Liston A, Piñero D. 2003. Phylogenetics of Pinus Subsections Cembroides and Nelsoniae Inferred from cpDNA Sequences. Systematic Botany 28: 657-673. DOI: 10.1043/02-63.1.

Hamrick JL, Murawski DA, Nason JD. 1993. The influence of seed dispersal mechanisms on the genetic structure of tropical tree populations. Vegetatio 107/108: 281-297. DOI: 10.1007/BF00052230.

Hardy OJ. 2003. Estimation of pairwise relatedness between individuals and characterization of isolation-by-distance processes using dominant genetic markers. Molecular Ecology 12:1577-1588. DOI: 10.1046/j.1365-294X.2003.01835.x.

Hernández-Velasco J, Hernández-Díaz JC, Fladung M, Cañadas-López Á, Prieto-Ruíz JÁ, Wehenkel C. 2017. Spatial genetic structure in four Pinus species in the Sierra Madre Occidental, Durango, Mexico. Can. J. For. Res. 47:73-80. DOI: 10.1139/cjfr-2016-0154.

Heuertz M, Vekemans X, Hausman JF, Palada M, Hardy OJ. 2003. Estimating seed vs. pollen dispersal from spatial genetic structure in the common ash. Molecular Ecology 12:24832495. DOI: 10.1046/j.1365-294X.2003.01923.x.

Hochberg Y. 1988. A sharper Bonferroni procedure for multiple tests of significance. Biometrika 75:800-802. DOI: 10.1093/biomet/75.4.800.

Hubbard JA, McPherson GR. 1997. Acorn selection by Mexican jays: a test of a tri-trophic symbiotic relationship hypothesis. Oecologia 110:143-146. DOI: 10.1007/s004420050142.

Huff DR, Peakall R, Smouse PE. 1993. RAPD variation within and among natural populations of outcrossing buffalograss [Buchloë dactyloides (Nutt.) Engelm.]. Theor. Appl. Genet. 86:927-934. DOI: 10.1007/BF00211043.

IUCN. 2015. The IUCN red list of threatened species -Version 2015-4. http://www.iucnredlist.org. Accessed 20 Nov 2015.

Krauss SL. 2000. Accurate gene diversity estimates from amplified fragment length polymorphism (AFLP) markers. Molecular Ecology 9:1241-1245. DOI: 10.1046/j.1365294x.2000.01001.x.

Leinemann L, Kleinschmit J, Fussi B, Hosius B, Kuchma O, Arenhövel W, Lemmen P, Kätzel R, Rogge M, Finkeldey R. 2014. Genetic composition and differentiation of sloe (Prunus spinosa L.) populations in Germany with respect to the tracing of reproductive plant material. Plant Syst. Evol. 300:2115-2125. DOI: 10.1007/s00606-014-1027-7.

Leinemann L, Steiner W, Hosius B, Kuchma O, Arenhövel W, Fussi B, Haase B, Kätzel R, Rogge M, Finkeldey R. 2013. Genetic variation of chloroplast and nuclear markers in natural populations of hazelnut (Corylus avellana L.) in Germany. Plant Syst. Evol. 299:369-378. DOI: 10.1007/s00606-012-0727-0.

Little Jr EL. 1977. Research in the pinyon-juniper woodland. In Proceedings of the workshop: Ecology, uses, and management of pinyon-juniper woodlands - Albuquerque, N.M, 24-25

PeerJ reviewing PDF | (2019:07:39338:1:1:NEW 19 Sep 2019) 
439

440

441

442

443

444

445

446

447

448

449

450

451

452

453

454

455

456

457

458

459

460

461

462

463

464

465

466

467

468

469

470

471

472

473

474

475

476

477

478

March 1977. Edited by Aldon, Earl F., and Loring, Thomas J., Department of Agriculture, Forest Service, Rocky Mountain Forest and Range Experiment Station, Fort Collins, CO, U.S. pp. 8-19.

López-Mata L. 2001. Proteins, amino acids and fatty acids composition of nuts from the Mexican endemic rarity, Pinus maximartinezii, and its conservation implications. Interciencia 26(12):606-610.

Luna-cavazos M, Romero-Manzanares A, García-Moya E. 2008. Afinidades en la flora genérica de piñonares del norte y centro de México: un análisis fenético. Rev. Mex. Biodivers. 79: 449-458.

Manly BFJ. 1997. Randomization, Bootstrap and Monte Carlo Methods in Biology. 2nd Edition. Chapman and Hall, London. Journal of the Royal Statistical Society: Series A (Statistics in Society).

McCue KA, Buckler ES, Holtsford TP. 1996. A Hierarchical View of Genetic Structure in the Rare Annual Plant Clarkia springvillensis. Conservation Biology 10:1425-1434. DOI: 10.1046/j.1523-1739.1996.10051425.x.

McCune B. 1988. Ecological Diversity in North American Pines. Am. J. Bot. 75:353. DOI: $10.2307 / 2443983$.

McKay JK, Latta RG. 2002. Adaptive population divergence: markers, QTL and traits. Trends Ecol. Evol. 17:285-291. DOI: 10.1016/S0169-5347(02)02478-3.

Mueller UG, Wolfenbarger LL. 1999. AFLP genotyping and fingerprinting. Trends Ecol. Evol. 14:389-394. DOI: 10.1016/S0169-5347(99)01659-6.

Nei M. 1972. Genetic Distance between Populations. Amer. Nat. 106:283-292. DOI: $10.1086 / 282771$.

Nei M. 1978. Estimation of average heterozygosity and genetic distance from a small number of individuals. Genetics 89:583-90.

Parker KC, Hamrick JL, Parker AJ, Nason JD. 2001. Fine-scale genetic structure in Pinus clausa (Pinaceae) populations: effects of disturbance history. Heredity 87:99-113. DOI: 10.1046/j.1365-2540.2001.00914.x.

Peakall R, Ruibal M, Lindenmayer DB. 2003. Spatial autocorrelational analysis offers new insights into gene flow in the Australian bush rat, Rattus fuscipes. Evolution 57:1182-1195. DOI: 10.1111/j.0014-3820.2003.tb00327.x.

Peakall R, Smouse PE. 2012. GenAlEx 6.5: genetic analysis in Excel. Population genetic software for teaching and research--an update. Bioinformatics 28:2537-2539. DOI: 10.1093/bioinformatics/bts460.

Petit C, Fréville H, Mignot A, Colas B, Riba M, Imbert E, Hurtrez-Boussés S, Virevaire M, Olivieri I. 2001. Gene flow and local adaptation in two endemic plant species. Biol. Conserv. 100:21-34. DOI: 10.1016/S0006-3207(00)00204-4.

Richardson D. 2000. Ecology and biogeography of Pinus. Cambridge University Press, 2000. Rousset F. 2002. Inbreeding and relatedness coefficients: what do they measure? Heredity 88:371-380. DOI: 10.1038/sj.hdy.6800065. 
479 Rousset F. 2004. Genetic structure and selection in subdivided populations. Princeton Univ. 480 Press, Princeton, NJ.

481 Rzedowski J. 1978. Vegetación de México. Ed. Limusa. 4a. Reimpresión. México, DF México. 482 Segelbacher G, Cushman SA, Epperson BK, Fortin M-J, Francois O, Hardy OJ, Holderegger R,

483

484

485

486

487

488

489

490

491

492

493

494

495

496

497

498

499

500

501

502

503

504

505

506

507

508

509

510

511

512

513

514

515

516

517

Taberlet P, Waits LP, Manel S. 2010. Applications of landscape genetics in conservation biology: concepts and challenges. Conserv. Genet. 11:375-385. DOI: 10.1007/s10592-0090044-5.

Simpson J. 1997. Amplified fragment length polymorphisms (AFLP's). Botanical Sciences 60: 119-122. DOI: 10.17129/botsci.1524.

Slatkin M, Arter HE. 1991. Spatial Autocorrelation Methods in Population Genetics. The Am. Nat. 138:499-517. DOI: 10.1086/285228.

Sokal RR, Wartenberg DE. 1983. A Test of Spatial Autocorrelation Analysis Using an Isolationby-Distance Model. Genetics 105(1): 219-237.

Sork VL, Davis FW, Smouse PE, Apsit VJ, Dyer RJ, Fernandez-M JF, Kuhn B. 2002. Pollen movement in declining populations of California Valley oak, Quercus lobata: Where have all the fathers gone? Mol. Ecol. 11(9): 1657-1668. DOI: 10.1046/j.1365294X.2002.01574.x.

Stingemore JA, Krauss SL. 2013. Genetic Delineation of Local Provenance in Persoonia longifolia : Implications for Seed Sourcing for Ecological Restoration. Restoration Ecology 21:49-57. DOI: 10.1111/j.1526-100X.2011.00861.x.

Streiff R, Labbe T, Bacilieri R, Steinkellner H, Glossl J, Kremer A. 1998. Within-population genetic structure in Quercus robur L. and Quercus petraea (Matt.) Liebl. assessed with isozymes and microsatellites. Molecular Ecology 7:317-328. DOI: 10.1046/j.1365294X.1998.00360.x.

Tomback DF, Linhart YB. 1990. The evolution of bird-dispersed pines. Evol. Ecol. 4: 185-219. DOI: $10.1007 / \mathrm{BF} 02214330$.

Van Dyck H, Baguette M. 2005. Dispersal behaviour in fragmented landscapes: Routine or special movements? Basic Appl. Ecol. 6: 535-545. DOI: 10.1016/j.baae.2005.03.005.

Vekemans X, Hardy OJ. 2004. New insights from fine-scale spatial genetic structure analyses in plant populations. Molecular Ecology. DOI: 10.1046/j.1365-294X.2004.02076.x.

Vos P, Hogers R, Bleeker M, Reijans M, Lee T Van De, Hornes M, Friters A, Pot J, Paleman J, Kuiper M, Zabeau M. 1995. AFLP: A new technique for DNA fingerprinting. Nucleic Acids Research 23:4407-4414. DOI: 10.1093/nar/23.21.4407.

Wehenkel C, Simental-Rodríguez SL, Silva-Flores R, Hernández-Díaz JC, López-Sánchez CA, Martínez-Antúnez P. 2015. Discrimination of 59 seed stands of various Mexican pine species based on 43 dendrometric, climatic, edaphic and genetic traits. Forstarchiv 86: 194201. DOI: $10.4432 / 0300-4112-86-194$.

Wright S. 1938. Size of population and breeding structure in relation to evolution. Science 87: $430-431$

Peer] reviewing PDF | (2019:07:39338:1:1:NEW 19 Sep 2019) 
518 Zeng LY, Xu LL, Tang SQ, Tersing T, Geng YP, Zhong Y. 2010. Effect of sampling strategy on 519 estimation of fine-scale spatial genetic structure in Androsace tapete (Primulaceae), an 520 alpine plant endemic to Qinghai-Tibetan Plateau. Journal of Systematics and Evolution. 521 48(4): 257-264. DOI: 10.1111/j.1759-6831.2010.00084.x. 


\section{Figure 1}

Location of the five Pinus cembroides seed stands under study.

Location of the five Pinus cembroides seed stands under study. Mesa Azul (PC-MA): black

square, Baquiriachi (PC-BQ): black diamond; Mesa de la Majada (PC-MM): small black square, Los Adobe (PC-AD): black circle and Cordon del Toro (PC-CT): white triangle. Source:

Available in the ARCGIS software (at Esri, DigitalGlobe, GeoEye, Earthstar Geographics, CNES/Airbus DS, USDA, USGS, AEX, Getmapping, Aerogrid, IGN, IGP, swisstopo, and the GIS User Community). 


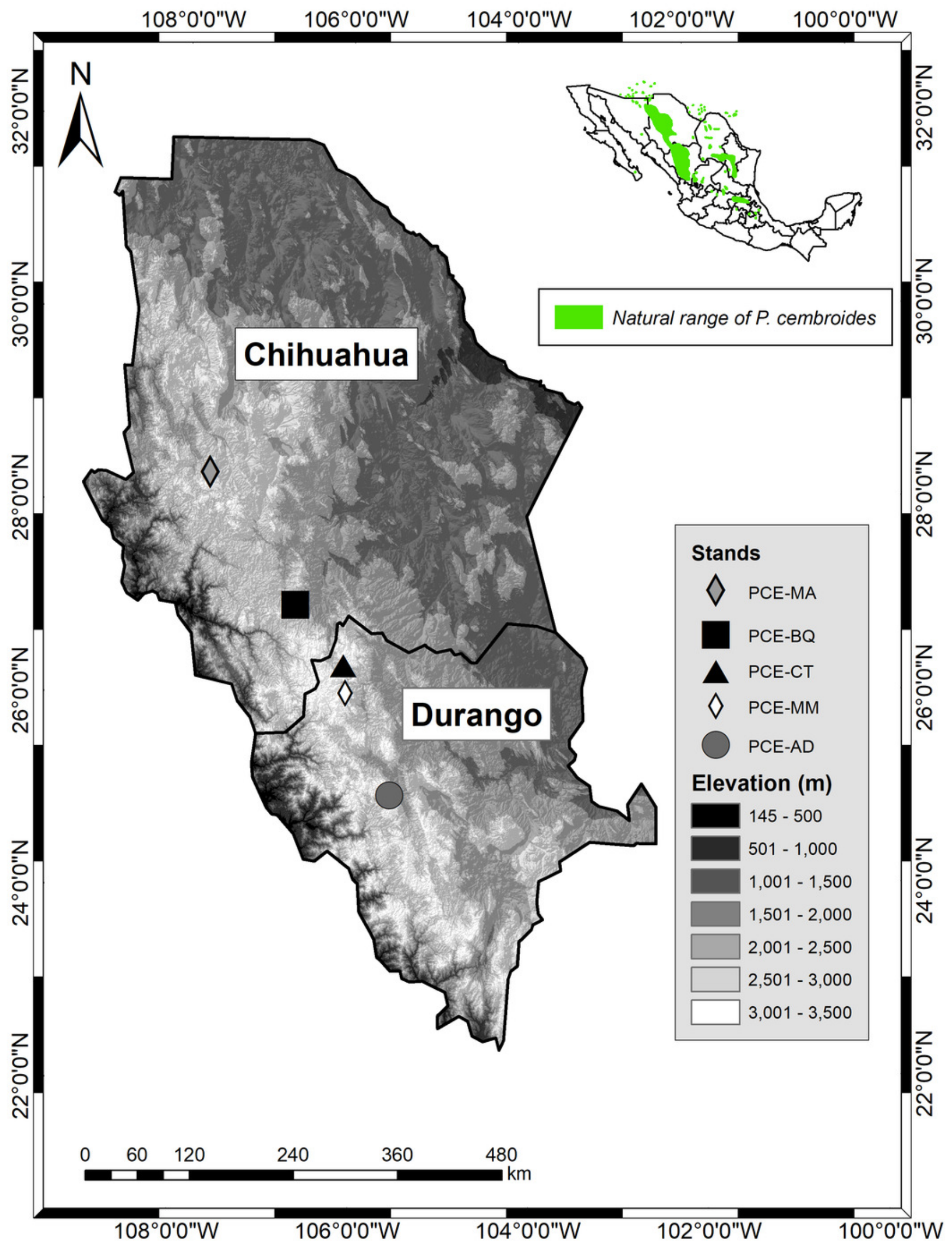


Figure 2

Principal Coordinates Analysis (PCoA) (coordinate 1 vs. 2) showing the genetic separation between the five seed stands of Pinus cembroides:

Principal Coordinates Analysis (PCoA) (coordinate 1 vs. 2) showing the genetic separation between the five seed stands of Pinus cembroides: Location with abbreviation of seed stand name: Mesa Azul (PC-MA): grey diamond, Baquiriachi (PC-BQ): black square, Los Adobe (PC$A D)$ : grey circle, Mesa de la Majada (PC-MM): white diamond and Cordon del Toro (PC-CT): grey triangle.

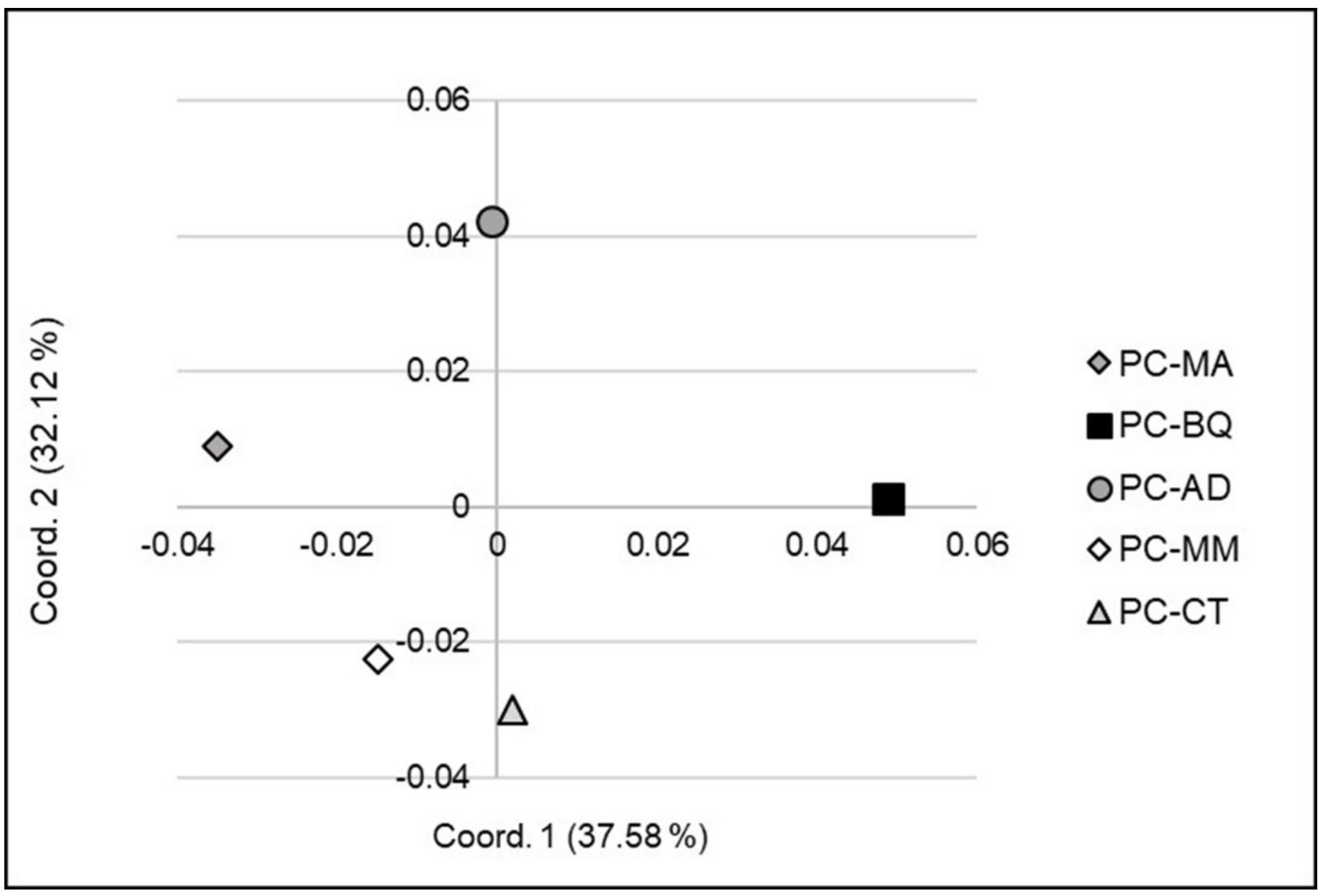


Figure 3

Principal Coordinates Analysis (PCoA) (coordinate 1 vs. 3) showing the genetic separation between the five Pinus cembroides seed stands:

Principal Coordinates Analysis (PCoA) (coordinate 1 vs. 3) showing the genetic separation between the five Pinus cembroides seed stands: Mesa Azul (PC-MA): grey diamond, Baquiriachi (PC-BQ): black square, Los Adobe (PC-AD): grey circle, Mesa de la Majada (PCMM): white diamond and Cordon del Toro (PC-CT): grey triangle.

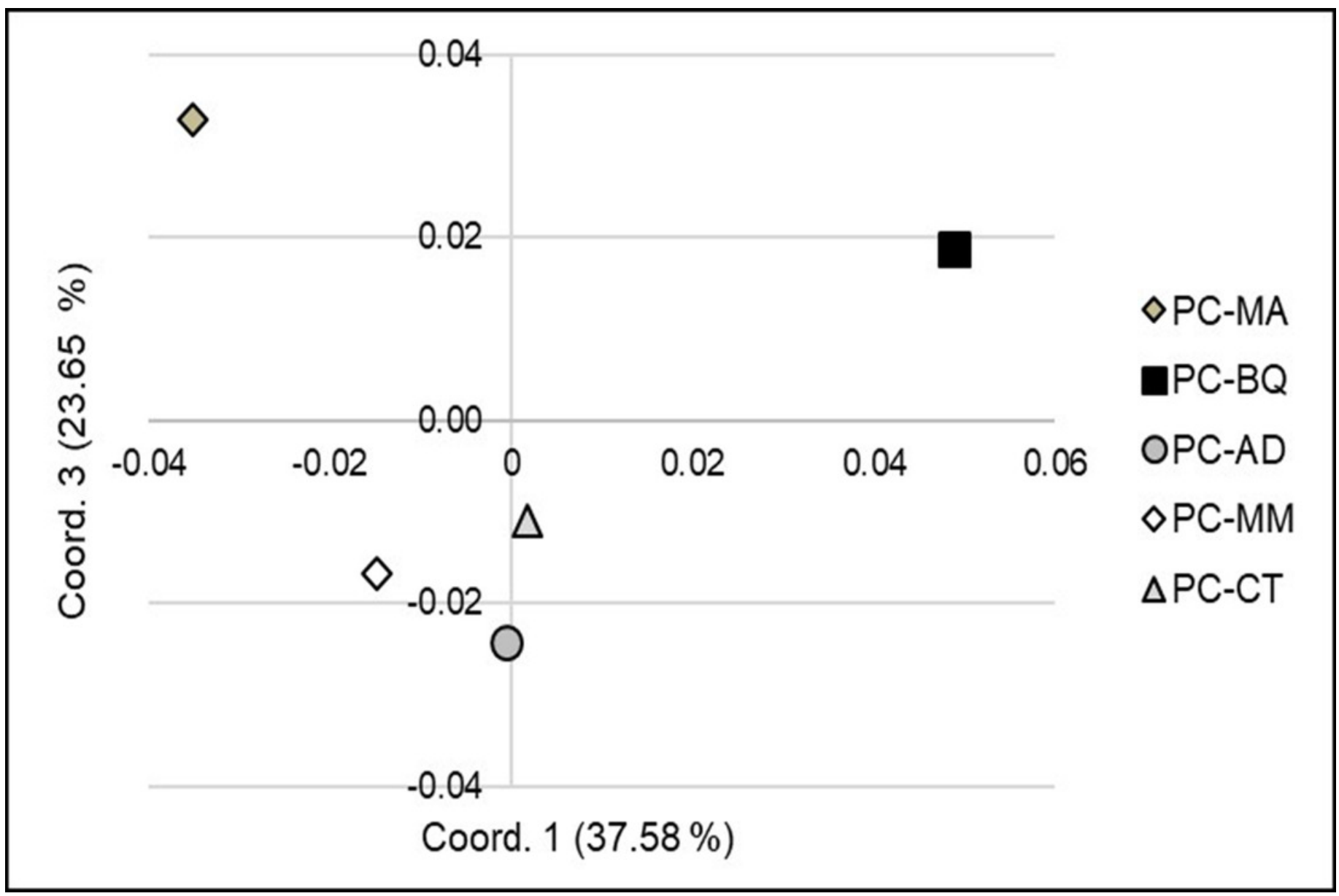


Figure 4

Principal Coordinates Analysis (PCoA) (coordinate 1 vs. 3) showing the genetic separation between the individuals in the five Pinus cembroides seed stands.

Principal Coordinates Analysis (PCoA) (coordinate 1 vs. 3) showing the genetic separation between the individuals in the five Pinus cembroides seed stands: Mesa Azul (PC-MA): grey diamond, Baquiriachi (PC-BQ): black square, Los Adobe (PC-AD): grey circle, Mesa de la Majada (PC-MM): white diamond and Cordon del Toro (PC-CT): grey triangle.

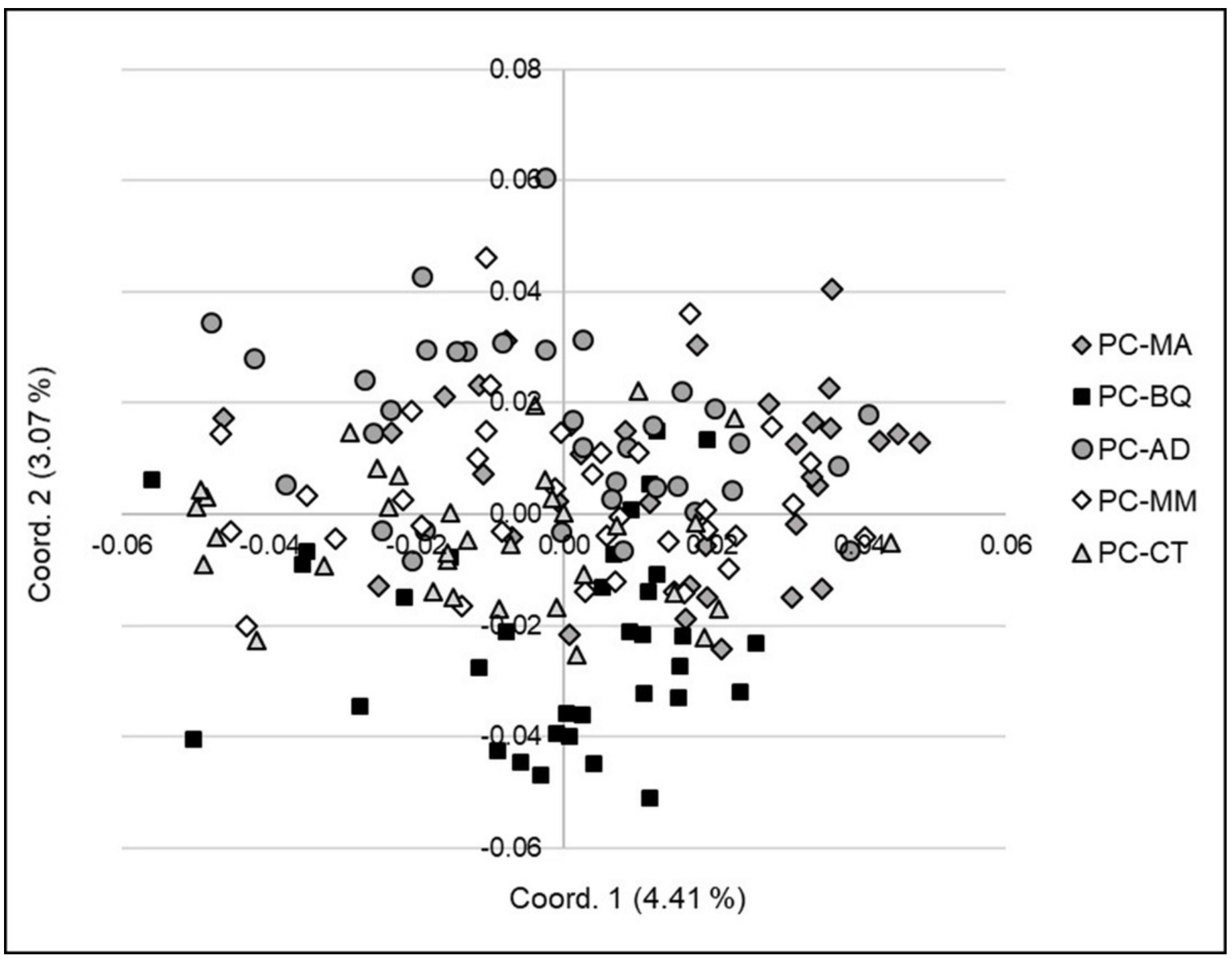


Figure 5

Map of the Pinus cembroides seed stand Mesa Azul (PC-MA) and the positions of the 34 sample trees genetically analyzed.

Map of the Pinus cembroides seed stand Mesa Azul (PC-MA) and the positions of the 34 sample trees genetically analyzed (black circles). Source: ESRI Inc. (1999-2012). ArcGIS for Desktop 10. USDA Natural Resources Conservation Service. 


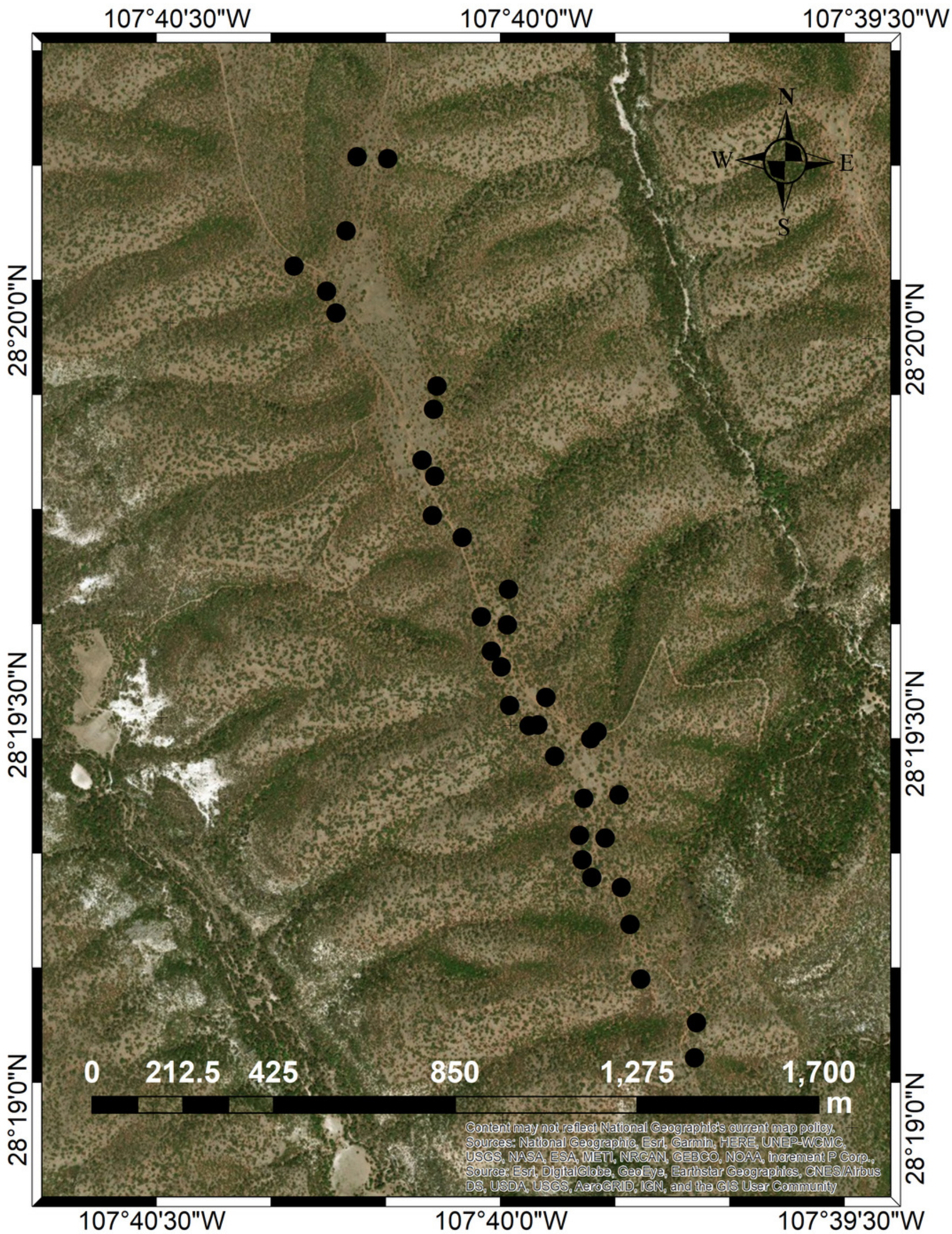




\section{Table $\mathbf{1}$ (on next page)}

Location of the five seed stands in the Sierra Madre Occidental in the states of Chihuahua and Durango, Mexico.

Location of the five seed stands in the Sierra Madre Occidental in the states of Chihuahua and Durango, Mexico. 
1

\begin{tabular}{|c|c|c|c|c|c|c|c|c|}
\hline Code & $\begin{array}{l}\text { Forest } \\
\text { stand }\end{array}$ & $\mathbf{N}$ & $\begin{array}{l}\text { MD } \\
\text { (m) }\end{array}$ & $\begin{array}{l}\text { Stand } \\
\text { size } \\
\text { (ha) }\end{array}$ & $\begin{array}{c}\text { Forest } \\
\text { property, } \\
\text { Municipality }\end{array}$ & Latitude (N) & Longitude (W) & $\begin{array}{l}\text { Elevation } \\
\text { (m) }\end{array}$ \\
\hline $\begin{array}{l}\text { PC- } \\
\text { MA }\end{array}$ & $\begin{array}{l}\text { Mesa } \\
\text { Azul }\end{array}$ & 34 & 77 & 14.7 & $\begin{array}{l}\text { Bilaguchi, } \\
\text { Guerrero }\end{array}$ & $28^{\circ} 19^{\prime} 5.04^{\prime \prime}$ & 107³9’43.57" & 2,218 \\
\hline $\begin{array}{l}\text { PC- } \\
\text { BQ }\end{array}$ & $\begin{array}{l}\text { Baqui- } \\
\text { riachi }\end{array}$ & 34 & 81 & 25.7 & $\begin{array}{l}\text { Baquiriachi, } \\
\text { Balleza }\end{array}$ & $26^{\circ} 57^{\prime} 0.20^{\prime \prime}$ & $106^{\circ} 38^{\prime} 43.41^{\prime \prime}$ & 2,369 \\
\hline $\begin{array}{l}\text { PC- } \\
\text { MM }\end{array}$ & $\begin{array}{l}\text { Mesa de } \\
\text { la } \\
\text { Majada }\end{array}$ & 35 & 72 & 28.9 & $\begin{array}{l}\text { Ciénaga Prieta, } \\
\text { Guanaceví }\end{array}$ & $26^{\circ} 15^{\prime} 8.60^{\prime \prime}$ & $106^{\circ} 4^{\prime} 12.41^{\prime \prime}$ & 2,631 \\
\hline $\begin{array}{l}\text { PC- } \\
\mathrm{CT}\end{array}$ & $\begin{array}{l}\text { Cordón } \\
\text { del Toro }\end{array}$ & 35 & 54 & 8.6 & $\begin{array}{l}\text { El Toro y } \\
\text { Anexos, } \\
\text { Guanaceví }\end{array}$ & $26^{\circ} 19^{\prime} 20.27^{\prime \prime}$ & $105^{\circ} 5^{\prime} 3.14^{\prime \prime}$ & 2,499 \\
\hline $\begin{array}{l}\text { PC- } \\
\text { AD }\end{array}$ & $\begin{array}{l}\text { Los } \\
\text { Adobe }\end{array}$ & 35 & 66 & 8.7 & $\begin{array}{l}\text { Garame de } \\
\text { Abajo, Santiago } \\
\text { Papasquiaro }\end{array}$ & $24^{\circ} 58^{\prime} 22.79^{\prime \prime}$ & $105^{\circ} 32^{\prime} 41.20^{\prime \prime}$ & 2,331 \\
\hline
\end{tabular}

2 Note: $\mathrm{N}=$ sample size, $\mathrm{MD}=$ mean distance to the next tree. Data from Wehenkel et al. (2015).

3 


\section{Table 2 (on next page)}

Some climate and soil conditions of the five Pinus cembroides seed stands studied.

Some climate and soil conditions of the five Pinus cembroides seed stands studied in the Sierra Madre Occidental in the states of Chihuahua and Durango, Mexico (locations listed in Table 1). 
1

\begin{tabular}{lcccccc}
\hline Code & Mat $\left({ }^{\circ} \mathrm{C}\right)$ & $\operatorname{Map}(\mathrm{mm})$ & $\operatorname{Mmin}\left({ }^{\circ} \mathrm{C}\right)$ & $\operatorname{Mmax}\left({ }^{\circ} \mathrm{C}\right)$ & $\mathrm{Gsp}(\mathrm{mm})$ & $\mathrm{pH}$ \\
\hline PCE-MA & 11.8 & 689 & -5.1 & 28.2 & 510 & 5.54 \\
PCE-BQ & 12.3 & 627 & -4.3 & 27.3 & 498 & 5.71 \\
PCE-CT & 11.8 & 635 & -4.4 & 26.2 & 514 & 6.05 \\
PCE-MM & 11.0 & 644 & -5.0 & 25.3 & 516 & 6.05 \\
PCE-AD & 13.1 & 661 & -2.4 & 27.9 & 518 & 6.05 \\
\hline
\end{tabular}

2 Note: $\mathrm{pH}=$ Degree of acidity; Mat = Mean annual temperature; Map =Mean annual

3 precipitation; $\mathrm{Mmin}=$ Mean minimum temperature in the coldest month; $\mathrm{Mmax}=$ Mean

4 maximum temperature in the warmest month and Gsp = Growing season precipitation, April to 5 September.

6 


\section{Table 3 (on next page)}

Analysis of the genetic spatial structure within the different Pinus cembroides seed stands PC-MA, PC-BQ and PC-MM.

Analysis of the genetic spatial structure within the Pinus cembroides seed stands PC-MA, PC-

BQ and PC-MM, considering the first class in distance class widths of 25-700 m, with 999

permutations. The analysis was conducted using SPAGeDi v1.4 (Vekemans \& Hardy, 2004). 
1

\begin{tabular}{|c|c|c|c|c|c|c|}
\hline \multicolumn{7}{|c|}{$F_{i j}$ vs. spatial distance } \\
\hline \multirow{3}{*}{$\begin{array}{c}\text { Distan } \\
\text { ce } \\
(\mathbf{m})\end{array}$} & \multirow{2}{*}{\multicolumn{2}{|c|}{$\begin{array}{c}\text { PC-MA } \\
C E=0.61^{* * *}\end{array}$}} & \multirow{2}{*}{\multicolumn{2}{|c|}{$\begin{array}{c}\text { PC-BQ } \\
C E=1.28 * *\end{array}$}} & \multirow{2}{*}{\multicolumn{2}{|c|}{$\begin{array}{c}\text { PC-MM } \\
C E=1.05 \mathrm{~ns}\end{array}$}} \\
\hline & & & & & & \\
\hline & $\begin{array}{c}P\left(F_{i j}\right)< \\
C I\end{array}$ & $F_{i j}$ & $\begin{array}{l}P\left(F_{i j}\right) \\
<C I \\
\end{array}$ & $F_{i j}$ & $\begin{array}{c}P\left(F_{i j}\right)< \\
C I\end{array}$ & $F_{i j}$ \\
\hline $\mathbf{0 - 2 5} \#$ & 0.277 & -0.085 & 0.523 & -0.029 & 0.473 & -0.031 \\
\hline $\mathbf{0 - 5 0} \# \#$ & 0.262 & -0.061 & 0.514 & -0.029 & 0.482 & -0.031 \\
\hline $0-75$ & 0.999 & 0.041 & 0.393 & -0.037 & 0.601 & -0.025 \\
\hline 0-100 & $0.9999^{+}$ & 0.030 & 0.553 & -0.027 & 0.608 & -0.026 \\
\hline $0-125$ & $0.9999^{+}$ & 0.020 & 0.244 & -0.038 & 0.921 & -0.016 \\
\hline $0-150$ & $0.9999^{+}$ & 0.009 & 0.195 & -0.038 & 0.867 & -0.019 \\
\hline $0-175$ & $0.9999^{+}$ & 0.006 & 0.276 & -0.034 & 0.912 & -0.020 \\
\hline $0-200$ & $0.9999^{+}$ & -0.001 & 0.498 & -0.030 & 0.838 & -0.023 \\
\hline $0-225$ & 0.993 & -0.007 & 0.520 & -0.031 & 0.527 & -0.029 \\
\hline $0-250$ & 0.994 & -0.011 & 0.755 & -0.027 & 0.549 & -0.029 \\
\hline $0-275$ & 0.984 & -0.015 & 0.448 & -0.031 & 0.6 & -0.028 \\
\hline 0-300 & 0.973 & -0.018 & 0.532 & -0.030 & 0.652 & -0.028 \\
\hline $0-350$ & 0.969 & -0.019 & 0.695 & -0.029 & 0.344 & -0.031 \\
\hline $0-400$ & 0.986 & -0.018 & 0.758 & -0.029 & 0.327 & -0.031 \\
\hline $0-450$ & 0.955 & -0.021 & 0.598 & -0.030 & 0.360 & -0.030 \\
\hline $0-500$ & 0.938 & -0.023 & 0.810 & -0.029 & 0.494 & -0.029 \\
\hline 0-550 & 0.910 & -0.024 & 0.707 & -0.030 & 0.512 & -0.029 \\
\hline $0-600$ & 0.897 & -0.026 & 0.650 & -0.030 & 0.194 & -0.031 \\
\hline $0-650$ & 0.876 & -0.026 & 0.266 & -0.031 & 0.218 & -0.030 \\
\hline 0-700 & 0.823 & -0.027 & 0.314 & -0.031 & 0.282 & -0.030 \\
\hline
\end{tabular}

2 Note: $F_{i j}=$ coefficient of kinship; $P=$ probability of autocorrelation at stand level; $C I=$

3 confidence interval, ${ }^{+}=$significant results after Bonferroni correction. $\#=$ significant

4 autocorrelation detected in the 50-75 m distance class in the PC-MA stand; \#\# = significant

5 autocorrelation detected in the 50-100 m distance class in the PC-MA stand; $C E=$ index of

6 aggregation. Asterisks indicate significant differences: $* *$ at the $99.0 \%$ and $* * *$ at $99.9 \%$ level;

7 ns $=$ not significant 


\section{Table 4 (on next page)}

Analysis of the genetic spatial structure within the different Pinus cembroides seed stands PC-CT and PC-AD.

Analysis of the genetic spatial structure within the Pinus cembroides seed stands PC-CT and PC-AD, considering the first class in distance class widths from 25-700 m, with 999 permutations and a confidence interval of $99 \%$. The analysis was conducted using SPAGeDi v1.4 (Vekemans \& Hardy, 2004). 
1

\begin{tabular}{|c|c|c|c|c|}
\hline \multirow{4}{*}{ Distance } & \multicolumn{4}{|c|}{$F_{i j}$ vs. spatial distance } \\
\hline & \multicolumn{2}{|c|}{ PC-CT } & \multicolumn{2}{|c|}{ PC-AD } \\
\hline & \multicolumn{2}{|c|}{$C E=1.05 \mathrm{~ns}$} & \multicolumn{2}{|c|}{$C E=0.31 * * *$} \\
\hline & $P\left(F_{i j}\right)<C I$ & $F_{i j}$ & $\begin{array}{c}P\left(F_{i j}\right)< \\
C I\end{array}$ & $F_{i j}$ \\
\hline $0-25$ & 0.903 & 0.072 & 0.964 & 0.010 \\
\hline $0-50$ & 0.981 & 0.053 & 0.953 & 0.010 \\
\hline $0-75$ & 0.464 & -0.031 & 0.966 & -0.003 \\
\hline $0-100$ & 0.127 & -0.041 & 0.999 & 0.005 \\
\hline 0-125 & 0.394 & -0.031 & 0.996 & -0.004 \\
\hline 0-150 & 0.329 & -0.032 & 0.983 & -0.012 \\
\hline 0-175 & 0.345 & -0.032 & 0.997 & -0.011 \\
\hline $0-200$ & 0.260 & -0.033 & 0.997 & -0.013 \\
\hline $0-225$ & 0.157 & -0.034 & 0.998 & -0.013 \\
\hline $0-250$ & 0.357 & -0.031 & 0.995 & -0.016 \\
\hline $0-275$ & 0.308 & -0.031 & 0.997 & -0.016 \\
\hline $0-300$ & 0.090 & -0.033 & 0.997 & -0.016 \\
\hline $0-350$ & 0.065 & -0.034 & 0.995 & -0.017 \\
\hline $0-400$ & 0.347 & -0.030 & 0.999 & -0.016 \\
\hline $0-450$ & 0.603 & -0.029 & 0.996 & -0.036 \\
\hline $0-500$ & 0.734 & -0.028 & 0.998 & -0.019 \\
\hline $0-550$ & 0.805 & -0.028 & 0.998 & -0.019 \\
\hline $0-600$ & 0.829 & -0.028 & 0.999 & -0.020 \\
\hline $0-650$ & 0.943 & -0.028 & 0.998 & -0.022 \\
\hline $0-700$ & 0.868 & -0.028 & 0.998 & -0.023 \\
\hline
\end{tabular}

2 Note: $F_{i j}=$ coefficient of kinship; $P=$ probability of autocorrelation at stand level; $C I=$

3 confidence interval; $C E=$ index of aggregation. Asterisks indicate significant differences: $* * *$ at $4 \quad 99.9 \%$ level; ns $=$ not significant 


\section{Table 5 (on next page)}

Analysis of the genetic spatial structure among the Pinus cembroides seed stands.

Analysis of the genetic spatial structure among the Pinus cembroides seed stands, considering a distance class size of $86 \mathrm{~km}, 999$ permutations and a confidence interval of 99\%. The analysis was conducted using SPAGeDi v1.4 (Vekemans \& Hardy, 2004). 
1

\begin{tabular}{|c|c|c|c|}
\hline \multicolumn{3}{|c|}{$F_{i j}$ vs. spatial distance (SPAGeDi v1.4) } & \multirow{2}{*}{$M T$} \\
\hline$F_{i j}$ & $P\left(F_{i j}\right)<C I$ & $P\left(F_{i j}\right)>C I$ & \\
\hline-0.000003 & $0.9999(0-86)^{+}$ & $\begin{array}{c}0.9999(86-172)^{+} \\
0.9999(172-258)^{+} \\
0.9999(258-344)^{+}\end{array}$ & 4,132 \\
\hline
\end{tabular}

2 Note: $F_{i j}=$ coefficient of kinship; $G D=$ mean genetic distance; $P(r)=$ probability of

3 autocorrelation per stand (in distance class, $\mathrm{m}$ ); $C I=$ confidence interval, $M T=$ minimal pairs of 4 trees for class (class distance); ${ }^{+}=$significant results after Bonferroni correction.

5 